\title{
Factors affecting the deep renovation of a single-family building - a case study
}

\author{
Triinu Bergmann ${ }^{1}$, Aime Ruus ${ }^{1 *}$, Kristo Kalbe ${ }^{2}$, Mihkel Kiviste $^{1}$ and Jiri Tintera ${ }^{1}$ \\ ${ }^{1}$ Tallinn University of Technology, School of Engineering, Tartu College, Puiestee 78 Tartu, Estonia \\ ${ }^{2}$ Tallinn University of Technology, School of Engineering, Department of Civil Engineering and Architecture, Ehitajate tee 5 Tallinn, \\ Estonia
}

\begin{abstract}
The Energy Performance of Buildings Directive (EPBD) of the EU states that Each Member State shall establish a long-term renovation strategy to support the renovation of building stock into a highly energy efficient and decarbonised building stock by 2050 . The motive for the study was the dissatisfaction of inhabitants of a single-family building about the heating costs and thermal discomfort. In this study both the emotional and resource efficiency aspects were considered. The structures and technical systems of the studied small dwelling are typical of representing single-family buildings of the Estonian building stock. The initial purpose was to improve the energy efficiency of a building while preserving the existing load bearing structures as much as possible. The research questions were: 1) what the situation before the renovation was, 2) what solutions can be used, 3) making decisions, whether to renovate or demolish. Calculations were carried out - the thermal transmittance of the envelope structures was calculated based on the construction information, and the linear thermal transmittance of geometrical thermal bridges was calculated by using the software Therm. Field tests performed - the thermography and the air leakage of the building was found by standard blower-door test. Specific air leakage rate $\mathrm{q}_{\mathrm{E} 50}=11.1 \mathrm{~m}^{3} /\left(\mathrm{hm}^{2}\right)$ was estimated. A renovation solution was offered considering the need for extra insulation and airtightness. The dwelling energy performance indicator was reduced from the existing $279 \mathrm{kWh} /\left(\mathrm{m}^{2} \mathrm{y}\right)$ to $136 \mathrm{kWh} /\left(\mathrm{m}^{2} \mathrm{y}\right)$. For significant energy efficiency improvement deep renovation measures must be used and the question was whether it is rational. Before making the final decision, several aspects have to be considered: 1) emotional - the demolition or renovation of somebody's home, 2) environmental aspects and resource-efficiency - the possibilities of the reuse of materials.
\end{abstract}

\section{Introduction}

The Energy Performance of Buildings Directive of the EU (EPBD 2018/844/EU) states that each member state shall establish a long-term renovation strategy to support the renovation of building stock into a highly energy efficient and decarbonised building stock by 2050 [1]. Many regulations and standards enable to evaluate the technical condition and thermal properties, airtightness and energy efficiency of buildings [2]-[9]. It is debatable whether demolishing the old building and constructing a new one, or renovating the existing building considering solely cost efficiency is the most reasonable choice. Other aspects might be worth considering also. For example, emotional aspects. Individuals or groups have strong emotional connections with a particular geographical locale and people develop attachment to physical places [10]. Individuals react to a place emotionally rather than rationally; a place evokes feelings among individuals. Hospers [11] has introduced the term "location-specific capital" that any place carries, and he defines this capital as emotional and socio-economic ties of an individual with a place. Alongside neighbourhood integration, social networks and job-related assets, home ownership is according to him one of the most important ties people develop with a place. A similar aspect of individual emotional attachment with a place can by described by the concept of "Genius Loci" according to Jiven and Larkham [12]. "Genius Loci" means the distinctive atmosphere of a place or a "character of a place". It is one's identity that is closely linked with the form and history of place which forms genius loci [12].

Place attachment entails an emotional bond between a person and setting and consists of place dependence and place identity. Place dependence refers to the ability of a setting to meet instrumental needs. Place identity is the extent to which a place becomes a crucial symbolic component of one's definition of self [10].

Individual's ties with his/her home plays an important role in one's identity. Home settings need to meet the instrumental needs of the inhabitant, home needs to offer a suitable standard of living to its inhabitants. But those aspects are not only ones an individual considers when deciding whether to renovate or rebuild their home. The history of the place, their own life memories, and familiar home setting are important factors supporting the decision to save the home building. People are particularly tied to their individual

\footnotetext{
*Corresponding author: aime.ruus@taltech.ee
} 
house if they have been participating manually in its construction, which was a frequent case during the Soviet times in Estonia. It is emotionally hard to remove something you have built yourself.

Nevertheless, the construction and service of buildings are responsible for the utilization of $40 \%$ of global resources and $30-40 \%$ of all primary energy [13]. The International Resource Panel has found in their report that over the past? four decades the global extraction of materials has tripled; from 22 billion tonnes (1970) to 70 billion tonnes (2010) [14].

Improved resource efficiency in the construction industry is needed to balance the sustainability requirements with growing demand for new infrastructure. Resource efficiency includes the reduction of primary and non-renewable materials, the creation of high-quality products with minimal waste, and the retention of long-term product value [15].

The most common and practical method for assessing the environmental impact of materials is life cycle approach. The methodology for life cycle analysis is given in ISO 14040 [16], which helps to assess systematically the environmental impact of a product or process [17]. The procedures for implementing the methodology are described in ISO 14040 [16] and ISO 14044 [18] standards. The most common stages in product input energy and waste assessment in the terms of its life cycle are "from cradle to gate" and "from cradle to grave" approaches [19]. In addition, "from cradle to cradle", "cradle to site" and "site to grave" approaches are used [20]-[22]. Conversion factors are used to convert the energy used in the production of materials into pollutants. The most common publishers of pollution factors are ICE (Inventory of Carbon and Energy) and EPD (Environmental Product Declaration).

The motive for the study in our case was the dissatisfaction of the inhabitants of a single-family building about the heating costs and the thermal discomfort.

In this study both the emotional and resource efficiency aspects were considered. The structures and technical systems of the studied small dwelling are typical of similar small buildings of the Estonian building stock.

The objectives of the study are to propose a renovation solution that directly addresses the main complaints of the habitants and explore other factors such as the emotional aspects and environmental impact of the renovation.

\section{Materials and methods}

\subsection{Case study building}

The case study building was built in 1987 as a onestorey summer cottage with a cold attic. It has been partly renovated and converted for all year use during the years $2000-2010$ and is now a home for a family (Figure 1, 2). The attic has been converted to living space and the total heated area is now $116 \mathrm{~m}^{2}$.

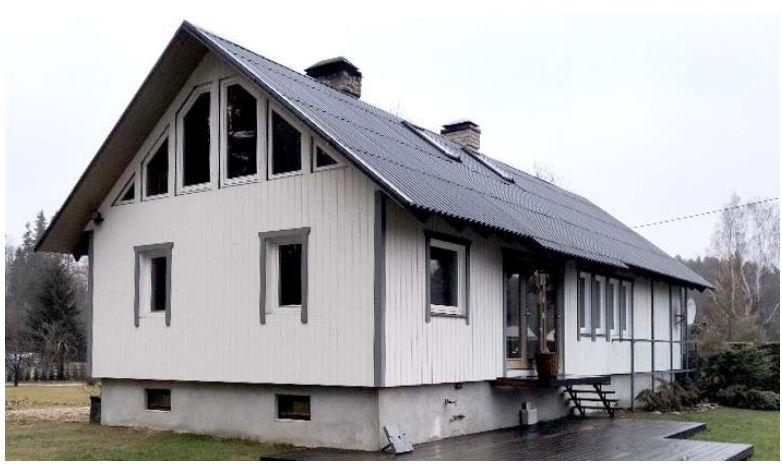

Figure 1. View from west of the single-family building before renovation.

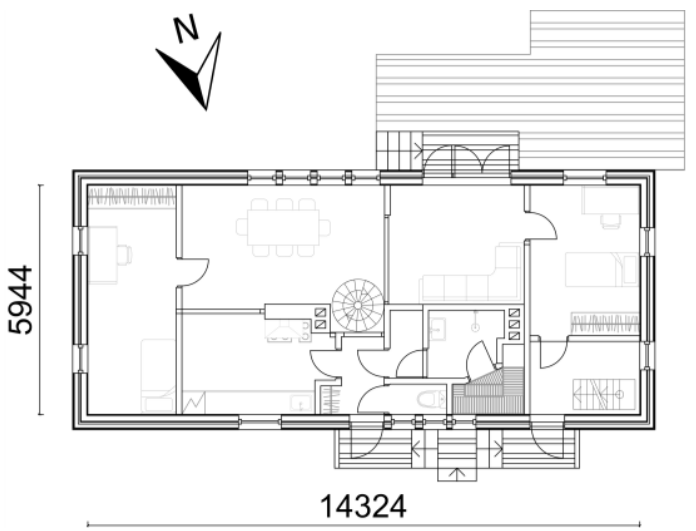

Figure 2. Floor plan of the building before renovation with internal dimensions given.

Converting summer cottages to all year use is rather common in Estonia - e.g., in the close vicinity of the case study building there are 7 cottages out of 11 which are used all year round.

The building has natural ventilation: exhaust from the kitchen and sauna, without extra inlets. Outdoor air enters via air leakages. The annual need for firewood is $35 \mathrm{~m}^{3}$. Assuming a calorific value of $1,295 \mathrm{kWh} / \mathrm{m}^{3}$ [23] for the firewood at a moisture content of $20 \%$, makes the annual energy demand of the unrenovated building to be $45,325 \mathrm{kWh}$. This approximates to a weighted energy use of $326 \mathrm{~kW} /\left(\mathrm{m}^{2} \mathrm{y}\right)$ (energy class $\mathrm{F}$ ). The weighted energy use is calculated as the product of delivered energy and of the energy carrier conversion factor $(0.65$ for biomass in Estonia [4]) per heated area.

The question about further or "deep renovation" arose because of too high expenses on heating and discomfort characteristic to air leakages - draught in the room and from plugs, also cold floors. Additionally, the habitants felt discomfort in a too frequent need to heat the oven.

\subsection{Airtightness}

One of the main concerns of the habitants was discomfort due to air leakages and it was thus necessary to measure the air leakage and map leakage points. Previous studies have shown that older buildings can have very high levels of air leakage [24], [25]. Knowledge about critical leakage points is very important to plan a moisture safe and durable renovation solution. 
A blower door test was carried out according to EVS-EN-ISO 9972:2015 [7] with Minneapolis BlowerDoor Model 4 and a pressure gauge DG1000. Critical leakage points were identified with a smoke generator and infrared thermal camera Flir E6 (thermal sensitivity $<0.06{ }^{\circ} \mathrm{C}$ ) during underpressurization [8]. The outside temperature was $\approx 10{ }^{\circ} \mathrm{C}$ during the blowerdoor test but had been as low as $2{ }^{\circ} \mathrm{C}$ during the previous $12 \mathrm{~h}$.

The existing thermal envelope does not have a dedicated vapour barrier (Figure 3Error! Reference source not found.). A durable renovation solution has to implement a continuous vapour-retarding layer on the interior surface of the thermal envelope.
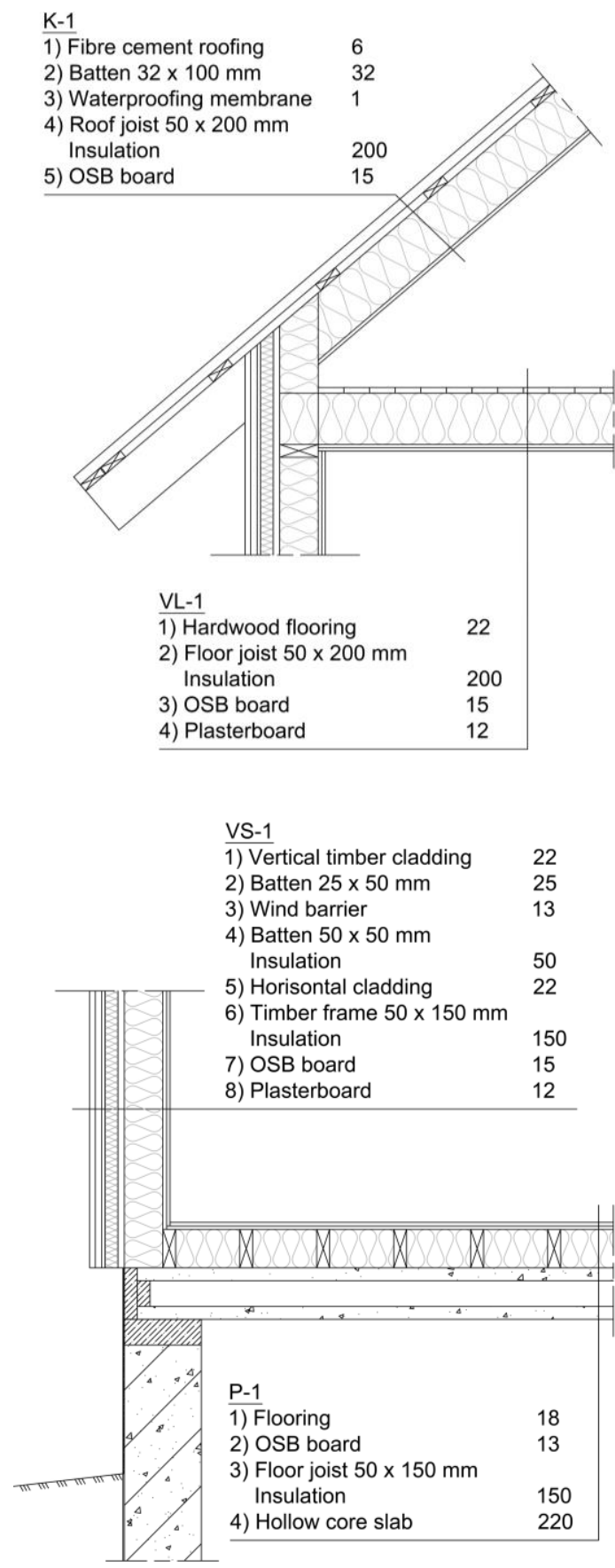

Figure 3. Exterior wall, intermediate ceiling and roof connection of the existing situation (top) and exterior wall and floor connection (bottom).

\subsection{Heat loss calculations}

Transmission loss of the building envelope was calculated according to the ISO 13789:2017 standard [26] to analyse the possible energy improvements of the renovation. Heat transfer coefficients were calculated for the initial and improved thermal envelope. Changes in solar gain, indoor heat gain, ventilation heat recovery, heating system efficiency were not considered. The thermal transmittance [3] of the envelope structures and linear thermal transmittance of geometrical thermal bridges were used as an input for this calculation. Linear thermal transmittances were calculated in LBNL Therm 7 according to ISO 10211:2017 [5] and ISO 14683:2017 [6].

\subsection{Environmental impact of materials}

The amount of material was calculated based on the construction and renovation drawings of the singlefamily building. The values from ICE (Inventory of Carbon \& Energy; V3.0 - 10 Nov 2019) database [27] were applied for the embodied energy and embodied carbon calculations of the materials. For the studied materials, the "cradle to gate" approach was applied as a boundary condition in ICE database for the embodied energy and embodied carbon. Only very few materials and products were selected to represent different material (sawn timber, wooden strand, concrete, mineral wool) and construction element groups (bearing structure or insulation).

\subsection{Emotional aspects}

Emotional aspects were evaluated considering the owner's attachment to the place. The owner erected the building during the 1980s as a summer house for his family. When he decided to use the house for year-round living at the beginning of this century, he renovated the house for this purpose. Both construction and renovation have been done largely manually by the owner. The owner saw his children growing in the house, an important part of his life has passed there. His attachment to the house is therefore strong and he desires to keep the structure.

\section{Results}

\subsection{Air leakage test and leak detection}

Measured air leakage at reference pressure difference $(50 \mathrm{~Pa})$ was $\mathrm{q}_{50}=3539 \mathrm{~m}^{3 /} \mathrm{h}$ and specific leakage rate per building envelope area at the reference pressure difference was $\mathrm{q}_{\mathrm{E} 50}=3539 / 320=$ $11.1 \mathrm{~m}^{3} /\left(\mathrm{m}^{2} \mathrm{~h}\right)$.

The smoke generator and thermal imaging did not reveal definitive large air leakage spots. It was deducted that most of the air leakage is due to uniform leakage over the entire thermal envelope. The air permeability of the $13 \ldots 15 \mathrm{~mm}$ thick OSB board used in the walls and 
roof might be too high. Other researchers have linked the air permeability of OSB boards to their thickness and manufacturing technology [28], [29].

Nevertheless, critical leakage paths were detected at the chimney and roof connection (Figure 4), exterior wall to roof connection (Figure 5) and around windows (Figure 6).

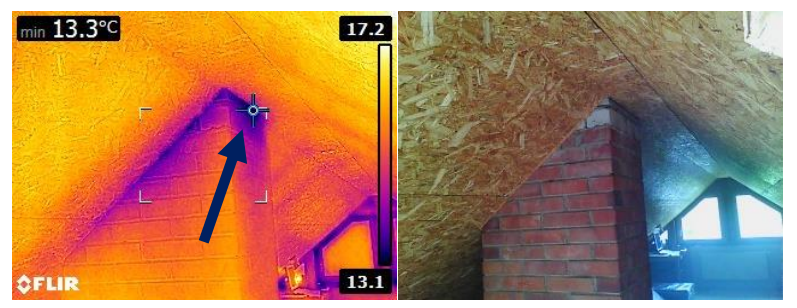

Figure 4. Roof and chimney connection. Minimum temperature of $13.3^{\circ} \mathrm{C}$ due to air leakages

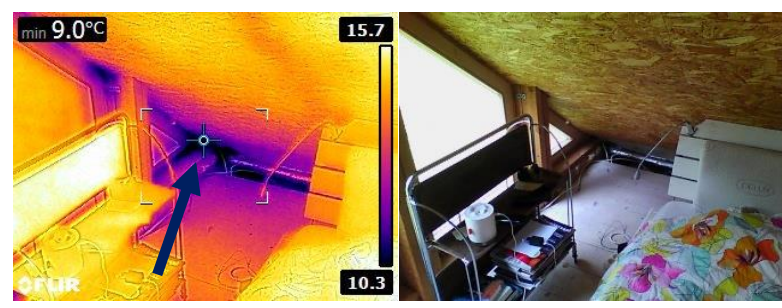

Figure 5. Roof, intermediate ceiling, exterior wall and window connection. Minimum temperature of $9.0^{\circ} \mathrm{C}$ at the window corner. This building side had not received direct sunlight prior to the thermal imaging.

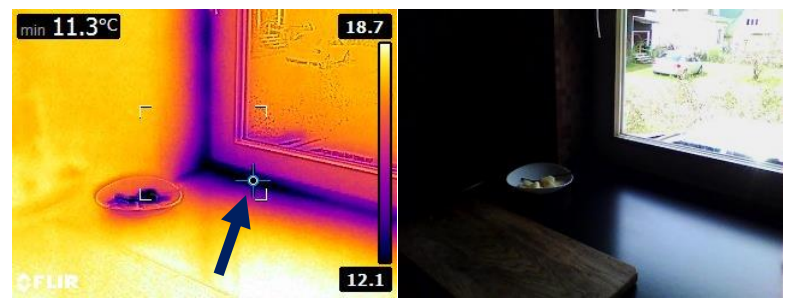

Figure 6. Window and wall connection. Minimum temperature of $11.3^{\circ} \mathrm{C}$ at the edge of an operable window.

\subsection{Proposed renovation solution and energy demand}

A renovation solution was proposed considering the need for extra insulation and for a functional airtightness layer. Most of the materials excluding the bearing structures and foundation would be replaced.

The air leakage test indicated air leaks around the chimney and at the perimeter of the roof to exterior wall connection. This connection is rather complicated to solve because the intermediate ceiling load bearing structure should be left unchanged. This implies that each ceiling beam would penetrate the airtight layer. A solution was proposed to install a $22 \mathrm{~mm}$ thick OSB board as a vapour tight layer on the exterior wall, between the ceiling beams, and tape the perimeter of each ceiling beam onto the OSB board (Figure 7Error! Reference source not found.). For the ceiling, a vapour retarding membrane was proposed to be used, which must be taped to the OSB board of the exterior wall. This will create a continuous air and vapour tight layer on the exterior perimeter. The thermal imaging and smoke test also indicated a leak around the chimney. We propose to seal the chimney with fire retardant aluminium foil tape which in turn must be connected to a non-combustible vapour barrier or a non-combustible cantilever plate with a length that provides the minimum distance to combustible materials if regular vapour retarding membrane is used elsewhere (Figure 8).

The renovation solution is proposed in two versions: 1) assuming a reduction of the specific air leakage to the level of the base value of a renovated building in Estonia, $\mathrm{q}_{\mathrm{E} 50}=4 \mathrm{~m}^{3} /\left(\mathrm{hm}^{2}\right)$ ) or 2$)$ to the level of $\mathrm{q}_{\mathrm{E} 50}=$ $1.5 \mathrm{~m}^{3} /\left(\mathrm{hm}^{2}\right)$, which is allowed to be used as an input in energy calculations in Estonia when an airtightness test is planned. This level could be achieved if all the joints of the inside OSB boards, window openings, vapour retarding membrane and penetrations are sealed properly. In Table 1 there is a summary of the thermal transmittances and calculated transmission heat losses of the unrenovated solution and renovation proposal. On Figure 9, there is the overall section cut drawing of the proposed renovation solution.

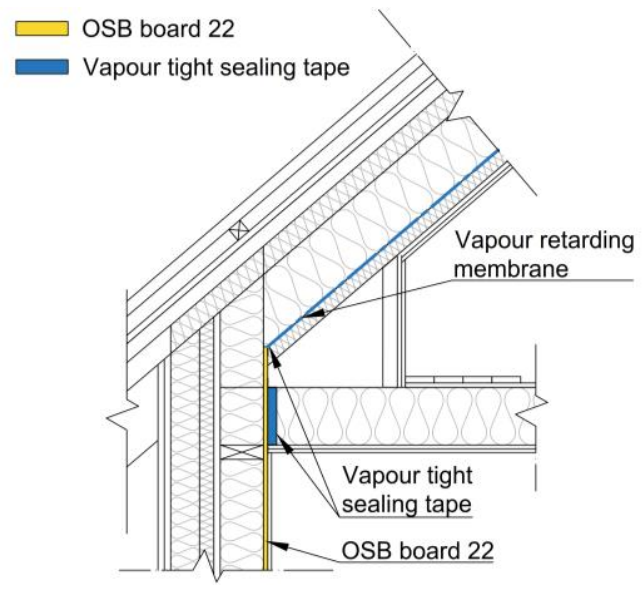

Figure 7. Exterior wall, roof and intermediate ceiling connection for the proposed renovation solution.

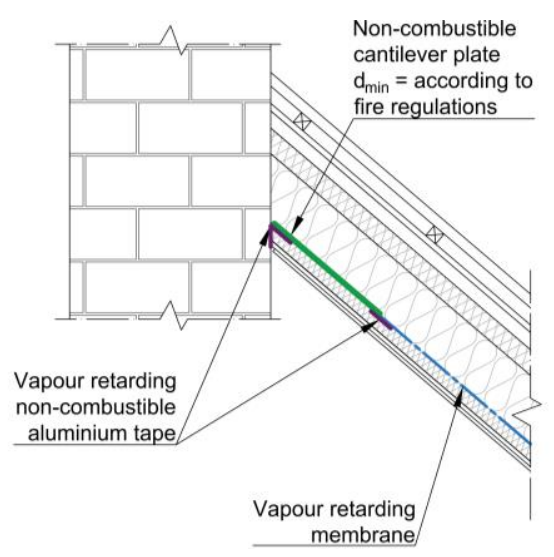

Figure 8. Roof and chimney connection of the proposed renovation solution. 
Table 1. Summarised data of the building envelope properties before and after renovation.

\begin{tabular}{|c|c|c|c|c|c|c|}
\hline \multirow{2}{*}{ Component } & \multicolumn{3}{|c|}{$\begin{array}{l}\text { Thermal transmittance }\left(\mathrm{U}, \mathrm{W} /\left(\mathrm{m}^{2} \mathrm{~K}\right)\right) \\
\text { and specific air leakage rate }\left(\mathrm{q}_{\mathrm{E} 50}, \mathrm{~m}^{3} /\left(\mathrm{hm}^{2}\right)\right)\end{array}$} & \multicolumn{3}{|c|}{$\begin{array}{c}\text { Specific heat loss }(\mathrm{H}, \mathrm{W} / \mathrm{K})) \\
\text { and specific heat loss per heated area }\left(\mathrm{H} / \mathrm{A}, \mathrm{W} /\left(\mathrm{m}^{2} \mathrm{~K}\right)\right.\end{array}$} \\
\hline & $\begin{array}{l}\text { Before } \\
\text { renovation }\end{array}$ & $\begin{array}{c}\text { After } \\
\text { renovation v1 }\end{array}$ & $\begin{array}{l}\text { After } \\
\text { renovation v2 }\end{array}$ & $\begin{array}{l}\text { Before } \\
\text { renovation }\end{array}$ & $\begin{array}{l}\text { After renovation } \\
\text { v1 }\end{array}$ & $\begin{array}{l}\text { After renovation } \\
\quad \mathrm{v} 2\end{array}$ \\
\hline Walls & 0.22 & \multicolumn{2}{|c|}{0.11} & 25.4 & \multicolumn{2}{|c|}{12.7} \\
\hline Roof & 0.29 & \multicolumn{2}{|c|}{0.11} & 36.6 & \multicolumn{2}{|c|}{12.2} \\
\hline Floor & 0.22 & \multicolumn{2}{|c|}{0.17} & 17.6 & \multicolumn{2}{|c|}{14.5} \\
\hline Windows & 1.86 & \multicolumn{2}{|c|}{0.72} & 33.1 & \multicolumn{2}{|c|}{12.9} \\
\hline Doors & 2.8 & \multicolumn{2}{|c|}{0.8} & 10.7 & \multicolumn{2}{|c|}{4.8} \\
\hline Linear thermal bridges & & & & 22.1 & \multicolumn{2}{|c|}{6.2} \\
\hline Total transmission loss & & & & 145.5 & \multicolumn{2}{|c|}{63.3} \\
\hline Air leakages, $\mathrm{m}^{3} /\left(\mathrm{hm}^{2}\right)$ & $11.1^{\mathrm{a}}$ & $4^{b}$ & $1.5^{\mathrm{c}}$ & 53.9 & 19.1 & 7.1 \\
\hline $\begin{array}{l}\text { Total heat loss of building } \\
\text { envelope (incl. air leakages) }\end{array}$ & & & & 199.4 & 82.4 & 70.4 \\
\hline $\begin{array}{l}\text { Total heat loss of building } \\
\text { envelope per heated area }\end{array}$ & & & & 1.72 & 0.71 & 0.61 \\
\hline
\end{tabular}

${ }^{\mathrm{a}}$ Measured before renovation

${ }^{\mathrm{b}}$ Tabulated value for energy calculations if no air leakage measurements are planned

${ }^{\mathrm{c}}$ Value permitted for energy calculations if air leakage test is planned to be carried out

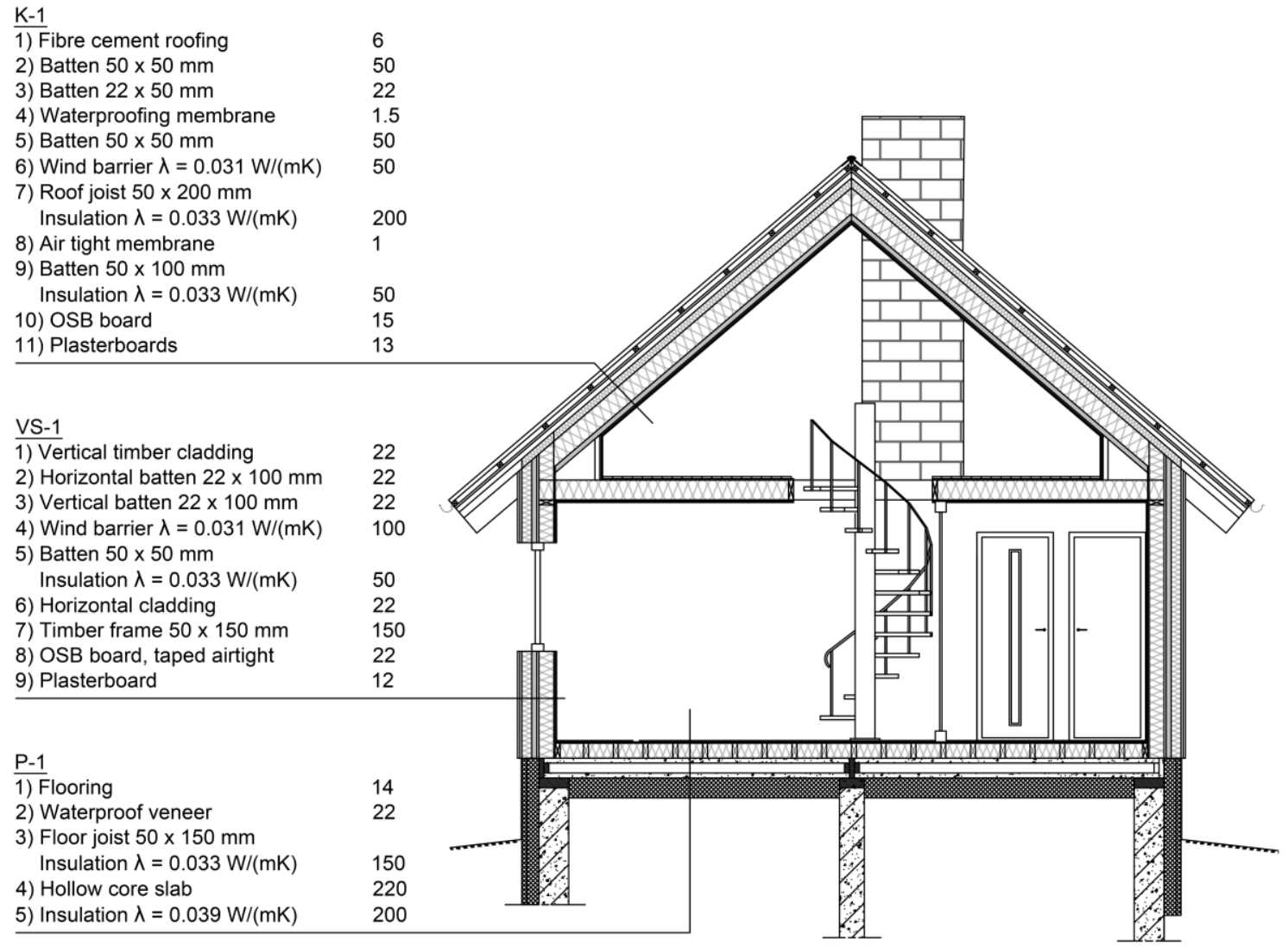

Figure 9. Cross section of the house with proposed new construction types after renovation.

Assuming the building envelope properties described above and a specific air leakage of $\mathrm{q}_{\mathrm{E} 50}=1.5 \mathrm{~m}^{3} /\left(\mathrm{hm}^{2}\right)$, the energy performance indicator was reduced from the existing $279 \mathrm{kWh} /\left(\mathrm{m}^{2} \mathrm{y}\right)$ to $136 \mathrm{kWh} /\left(\mathrm{m}^{2} \mathrm{y}\right)$ and the target for the new reconstructed building to be a near zero energy building was met. Effect was received mainly from reducing heating need - extra insulation and increasing airtightness $[147.9$ vs 74.6 or 61.7 $\left.\mathrm{kWh} /\left(\mathrm{m}^{2} \mathrm{y}\right)\right]$. Heating system (wood boiler) was retained. Effect from solar energy (panel $0.4 \mathrm{~kW}$ and solar collecter $\left.7.7 \mathrm{~m}^{2}\right)$ will result in $-5 \mathrm{kWh} /\left(\mathrm{m}^{2} \mathrm{y}\right)$. Rotary heat recovery aggregate with thermal efficiency $82 \%$ was chosen. 


\subsection{Environmental impact}

Table 2 shows the amounts of the embodied energy and embodied carbon of chosen materials like sawn timber, OSB boards, concrete panel and mineral wool. These amounts could be either spent or saved if the decision is to renovate partly by retaining/preserving some of the existing materials, or to replace them when building new. Table 2 also shows that the most embodied energy consuming material was OSB board and the most embodied carbon consuming material was concrete (mostly due to its larger mass), as its weight is more than ten times bigger than sawn timber in the walls. The embodied carbon per $\mathrm{kg}$ of the material is almost four times less than that of timber.

Table 2. Mass M (kg), Embodied energy EE (MJ; MJ/kg) and embodied carbon EC ( $\left.\mathrm{kgCO}_{2} \mathrm{e}\right)$ of construction materials from either wall or floor structures of the studied single-family building.

\begin{tabular}{|c|c|c|c|c|}
\hline Material & $\begin{array}{c}\text { Mass of } \\
\text { material, } \mathrm{kg}\end{array}$ & $\begin{array}{c}\text { Embodied energy, } \\
\mathrm{MJ} ; \mathrm{MJ} / \mathrm{kg}^{*}\end{array}$ & $\begin{array}{c}\text { Embodied carbon, } \\
\mathrm{kgCO}_{2} \mathrm{e} ; \mathrm{kgCO}_{2} \mathrm{e} / \mathrm{kg}^{*}\end{array}$ & Comment \\
\hline Sawn timber (50x150mm), walls & 1275 & $9065.3 / 7.11$ & $628.6 / 0.493$ & Retain \\
\hline OSB 15mm, walls & 1344 & $20092.8 / 14.95$ & $611.52 / 0.455$ & $\begin{array}{c}\text { Removed (needs } \\
\text { utilization or recycling) }\end{array}$ \\
\hline OSB board 22mm, walls, & 1971 & $\begin{array}{c}29466.5 / \\
14.95\end{array}$ & $896.8 / 0.455$ & New \\
\hline Concrete hollow-core panel 220 mm, floor & 26670 & $21869.2 / 0.82$ & $3360.4 / 0.126$ & Retain \\
\hline Mineral wool 150mm, walls & 527.5 & $8756.5 / 16.6$ & $675.2 / 1.28$ & Replaced \\
\hline
\end{tabular}

*values from ICE (Inventory of Carbon \& Energy; V3.0) database [27]. No carbon storage.

\section{Discussion and conclusions}

In the current study a small dwelling house was under investigation. Our study was very limited but novelty was planned to be in the complex approach how many aspects must be considered as a minimum if renovation decisions are made. Also, many aspects were not considered like cultural heritage value and cost benefit.

The question was about renovation: how, how much, why, whether it is necessary or reasonable. Similar questions arise for the owners of dwellings built before the 21 th century. Our building is originally from 1987 and used to be a summer cottage. Between 2000 and 2010 it was partly renovated. Today the inhabitants feel discomfort and the question was what should be done next.

The study showed that the calculated thermal transmittance parameters were quite acceptable compared with the Kredex renovation support measures requirements. The measured specific air leakage $\mathrm{q}_{\mathrm{E} 50}$ was $11.1 \mathrm{~m}^{3} /\left(\mathrm{hm}^{2}\right)$ which is comparable with unrenovated country houses $\mathrm{q}_{\mathrm{E} 50}=15 \mathrm{~m}^{3} /\left(\mathrm{hm}^{2}\right)$ [24] and wooden apartment houses $q_{E 50}=10 \mathrm{~m} 3 /(\mathrm{hm} 2)$ [25]. Several thermal bridges were discovered in the joints (window-wall, wall-roof).

The next question was if it is reasonable to renovate or build a new house keeping the foundation and technical utilities. If a similar question arose concerning a newly obtained property, it could be reasonable to build a new house.

Building something new will create the necessity of new materials having their own embodied energy and embodied carbon values, a lot of construction waste will be produced, which will in return create more $\mathrm{CO}_{2}$ emissions.

In our case it is a home - that is an important emotional aspect.
Adding extra insulation focusing on airtightness enables to improve the building energy class from $\mathrm{E}$ or $\mathrm{F}$ to A or B. Airtightness could be a key aspect in achieving class. If tabulated values $\mathrm{q}_{\mathrm{E} 50}=4.0 \mathrm{~m}^{3} /\left(\mathrm{hm}^{2}\right)$ are used, the maximum could be only B energy class and also there is a danger of not having adequate information about the building's air tightness.

If the decision is to renovate, a lot of building material will be saved and there is no need to recycle or dispose of materials.

Therefore, that amount of energy or carbon (Table 2) could be saved, which is a small step towards helping to preserve the environment. The embodied energy and carbon results of varied materials in Table 2 serve only as an example. It can be seen that by preserving the existing hollow-core concrete floor panels the largest amounts of embodied carbon will be saved. The carbon storage of materials has not been considered. Negative values would be obtained for unit wood-based materials in ICE database when the carbon storage was included (e.g. embodied carbon -1.03 of $\mathrm{kgCO}_{2} \mathrm{e} / \mathrm{kg}$ for sawn timber and -1.05 of $\mathrm{kgCO}_{2} \mathrm{e} / \mathrm{kg}$ for OSB boards). However, the data for carbon storage of concrete is missing in ICE database. It should be considered that the studied data set is limited to one single-family building and different results could be obtained when larger data sets are analysed.

The owner's clear will to save his home place has an important role in the decision whether to renovate or rebuild the house. His strong emotional attachment to the place needs to be taken into account.

Finally, what the outcome and useful information from this study is. The preliminary evaluation of the technical conditions of the building is essential before making any decisions whether it is an old or new property. Details (joints, air leakage) can hide surprises. The evaluation of airtightness, moisture damages and mould growth, which could be invisible, are strongly recommended. 
Often deep renovation with high expenses is necessary and there is a justified question is whether it is reasonable. A thorough inspection could be also useful for people looking for real-estate investments as only bearing constructions will be saved.

An important aspect is emotional value whether it is already a home or a house is still to be bought.

Relevant information about the technical condition of a building will enable to make better decisions and reduce stress and misunderstandings between the seller and the buyer. In current case owner stayed to the family's initial wish - renovate.

This study was supported by the European Comission through the "Operational Programmes adopted by the European Commission" project VFP21013 eMOTIONAL Cities.

\section{References}

[1] "DIRECTIVE (EU) 2018/844 OF THE EUROPEAN PARLIAMENT AND OF THE COUNCIL of 30 May 2018 amending Directive 2010/31/EU on the energy performance of buildings and Directive 2012/27/EU on energy efficiency (Text with EEA relevance)."

[2] International Organization for Standardization, ISO 13822:2010(en), Bases for design of structures - Assessment of existing structures. 2010.

[3] Estonian Centre for Standardisation and Accreditation, EVS 908-1:2016 Guidance for calculation of thermal transmittance of building envelope. Part 1: Opaque building envelope in contact with outdoor-air. 2016.

[4] Riigi Teataja, RT I, 13.12.2018, 14 Minimum energy performance requirements of buildings. 2018.

[5] International Organization for Standardization, ISO 10211:2017 Thermal bridges in building construction - Heat flows and surface temperatures - Detailed calculations. 2017.

[6] International Organization for Standardization, ISO 14683:2017 Thermal bridges in building construction - Linear thermal transmittance - Simplified methods and default values. 2017.

[7] International Organization for Standardization, ISO 9972:2015 Thermal performance of buildings - Determination of air permeability of buildings - Fan pressurization method. 2015.

[8] Estonian Centre for Standardisation and Accreditation, EVS-EN 13187:2001 Thermal performance of buildings - Qualitative detection of thermal irregularities in building envelopes - Infrared method. .

[9] International Organization for Standardization, ISO 9869-2:2018 Thermal insulation Building elements - In-situ measurement of thermal resistance and thermal transmittance
- Part 2: Infrared method for frame structure dwelling. 2018.

[10] J. M. Brehm, B. W. Eisenhauer, and R. C Stedman, "Environmental Concern: Examining the Role of Place Meaning and Place

Attachment," Soc. Nat. Resour., vol. 26, no. 5, pp. 522-538, May 2013, doi:

10.1080/08941920.2012.715726.

[11] G.-J. HOSPERS, "PLACE MARKETING IN SHRINKING EUROPE: SOME GEOGRAPHICAL NOTES," Tijdschr. voor Econ. en Soc. Geogr., vol. 102, no. 3, pp. 369375, Jul. 2011, doi: 10.1111/j.14679663.2011.00672.x.

[12] G. Jivén and P. J. Larkham, "Sense of place, authenticity and character: A commentary," $J$. Urban Des., vol. 8, no. 1, pp. 67-81, Feb. 2003, doi: 10.1080/1357480032000064773.

[13] United Nations Environment Programme, "Buildings and climate change: status, challenges and opportunities," UNEP, 2007. Accessed: Jan. 21, 2021. [Online]. Available: https://wedocs.unep.org/xmlui/handle/20.500.1 $1822 / 7783$.

[14] H. Schandl et al., Global Material Flows and Resource Productivity. 2016.

[15] F. Kedir and D. M. Hall, "Resource efficiency in industrialized housing construction - A systematic review of current performance and future opportunities," Journal of Cleaner Production, vol. 286. Elsevier Ltd, p. 125443, Mar. 01, 2021, doi: 10.1016/j.jclepro.2020.125443.

[16] International Organization for Standardization, ISO 14040:2006 Environmental management - Life cycle assessment - Principles and framework. 2006.

[17] V. Rodrigues, A. A. Martins, M. I. Nunes, A. Quintas, T. M. Mata, and N. S. Caetano, "LCA of constructing an industrial building: Focus on embodied carbon and energy," in Energy Procedia, Oct. 2018, vol. 153, pp. 420-425, doi: 10.1016/j.egypro.2018.10.018.

[18] International Organization for Standardization, ISO 14044:2006 Environmental management - Life cycle assessment - Requirements and guidelines. 2006.

[19] P. G. Hammond, C. Jones, E. F. Lowrie, and P. Tse, A BSRIA guide Embodied Carbon The Inventory of Carbon and Energy (ICE). 2011.

[20] J. D. Silvestre, J. De Brito, and M. D. Pinheiro, "Life-cycle assessment of thermal insulation materials for external walls of buildings," Int. Conf. Constr. - Towar. a Better Built Environ., no. October 2015, pp. 303-310, 2011, doi: 10.13140/RG.2.1.1756.7768.

[21] R. Carabaño, S. M. Hernando, D. Ruiz, and C. Bedoya, "Life cycle assessment (LCA) of building materials for the evaluation of building sustainability: The case of thermal insulation materials," Rev. la Constr., vol. 16, no. 1, pp. 22-32, 2017, doi: 
10.7764/RDLC.16.1.22.

[22] H. Jin and W. Ling, "External wall structure of green rural houses in Daqing, China, based on life cycle and ecological footprint theories," Front. Archit. Res., vol. 4, no. 3, pp. 212-219, Sep. 2015, doi: 10.1016/j.foar.2015.04.002.

[23] A. Konist, "Wood fuel." http://webcache.googleusercontent.com/search ?q=cache:6B6uGhK0QeAJ:staff.ttu.ee/ akonis t/sti/MST0120_files/Puitku\%25CC\%2588tuses t.pdf $+\& c d=1 \& \bar{h} \mathrm{l}=$ et $\& c t=c \operatorname{lnk} \& g l=e e($ accessed Jan. 21, 2021).

[24] T. Kalamees, Ü. Alev, E. Arumägi, S. Ilomets, A. Just, and U. Kallavus, Maaelamute sisekliima, ehitusfüüsika ja energiasääst I Uuringu I etapi lõpparuanne. 2011.

[25] T. Kalamees et al., "Eesti eluasemefondi puitkorterelamute ehitustehniline seisukord ning prognoositav eluiga," 2011.

[26] International Organization for Standardization, ISO 13789:2017 Thermal performance of buildings - Transmission and ventilation heat transfer coefficients - Calculation method. 2017.

[27] "Embodied Carbon Footprint Database Circular Ecology." https://circularecology.com/embodied-carbonfootprint-database.html (accessed Jan. 21, 2021).

[28] M. Hodoušek, M. Böhm, R. L. Lemaster, M. Bureš, J. Beránková, and J. Cvach, “Air permeation rate of oriented strand boards (OSB/3 and OSB/4)," BioResources, vol. 10, no. 1, pp. 1137-1148, 2015, doi: 10.15376/biores.10.1.1137-1148.

[29] J. Langmans, R. Klein, and S. Roels, "Langmans, J. et al; B: Air permeability requirements for air barrier materials in passive houses 15 th International Symposium on Building and Ductwork Air-tightness Air permeability requirements for air barrier materials in passive houses-Comparison of the air permeability of eight commercial brands of OSB.” Accessed: Jan. 22, 2021. [Online].

Available: www.europanels.org. 